Research Article

\title{
Cytogenetic studies in six species of Scinax (Anura, Hylidae) clade Scinax ruber from northern and northeastern Brazil
}

\author{
Lídia Nogueira $^{1}$, Juliani Bruna Zanoni ${ }^{2}$, Mirco Solé ${ }^{3}$, Paulo Roberto Antunes de Mello Affonso ${ }^{2}$, \\ Sérgio Siqueira ${ }^{2}$ and Iracilda Sampaio ${ }^{1}$ \\ ${ }^{1}$ Instituto de Estudos Costeiros, Universidade Federal do Pará, Bragança, PA, Brazil. \\ ${ }^{2}$ Departamento de Ciências Biológicas, Universidade Estadual do Sudoeste da Bahia, Jequié, BA, Brazil. \\ ${ }^{3}$ Departamento de Ciências Biológicas, Universidade Estadual de Santa Cruz, Ilhéus, BA, Brazil.
}

\begin{abstract}
Scinax species are still underrepresented in cytogenetic studies, mainly with respect to populations from northeastern and northern Brazil. In this study, we provide new chromosomal information on Scinax boesemani, S. camposseabrai, S. garbei, S. pachycrus, S. trilineatus and S. $x$-signatus, all belonging to clade $S$. ruber. They were collected at two locations in the Caatinga biome (northeastern Brazil) and at one in the Amazon (northern Brazil) biomes. Chromosomes were analyzed by conventional staining, C-banding, Ag-NOR staining, and fluorochrome staining. All species shared a modal diploid value of $2 n=24$ and fundamental arm number (FN) of 48 . Moreover, both chromosomal size and morphology were similar to other species in this Scinax clade. C-banding revealed centromeric heterochromatin in all species, along with terminal species-specific C-bands in some species. Active nucleolar organizer regions (Ag-NORs) were identified at 11q in most species, except for S. boesemani and S. garbei (Ag-NORs at interstitial region of 8q). Differing from most anurans, GC-rich regions were not restricted to NORs, but also coincident with some centromeric and terminal C-bands. These data contribute to the cytotaxonomy of Scinax by providing chromosomal markers and demonstrating the occurrence of microstructural rearrangements and inversions on chromosomal evolution of Scinax.
\end{abstract}

Keywords: amphibians, chromosomes, fluorochromes, heterochromatin, rDNA.

Received: September 26, 2014; Accepted: January 22, 2015.

\section{Introduction}

The genus Scinax (Anura: Hylidae) comprises 113 species widespread from southern Mexico to Argentina, Uruguay, Trinidad and Tobago and Santa Lucia islands (Frost, 2014). Based on molecular markers, morphology, osteology, myology, reproductive biology and chromosomes, this genus was divided into two clades: $S$. catharinae (which includes two species groups - $S$. catharinae and S. perpusillus) and S. ruber (species groups S. rostratus, $S$. uruguayus and the remaining species) (Faivovich, 2002; Faivovich et al., 2005). The clade S. ruber comprises nearly 65 species (Frost, 2014) widespread over open ares of tropical and subtropical regions (Faivovich, 2002).

So far, karyotypes are known for only 39 species of Scinax and only few studies included banding methods,

Sende correspondence to Lídia Nogueira. Instituto de Estudos Costeiros, Universidade Federal do Pará, Alameda Leandro Ribeiro s/n, Aldeia, 68600-000 Bragança, PA, Brazil. E-mail: lidia.nogueira@yahoo.com.br. such as Ag-NOR staining, C-banding, BrdU, fluorochrome staining, and in situ hybridization (Pombal et al., 1995; Kasahara et al., 2003; Nunes and Fagundes, 2008; Cardozo et al., 2011). These cytogenetic studies showed that all species in this genus share a modal diploid value of $2 \mathrm{n}=24$.

In spite of numerical conservativeness in diploid number, the two clades can be differentiated by cytogenetic analyses. In the clade $S$. catharinae, the first and second chromosomal pairs are submetacentric and NORs are usually located on the sixth pair, while, in the clade $S$. ruber, the first and second pairs are metacentric and NORs have been frequentle been detected on pair 11 (Cardozo et al., 2011).

Since Scinax species and populations are still underrepresented in terms of cytogenetic data, and speciesspecific or population differences might be overlooked, we herein provide the first chromosomal information about samples of the following species within the clade $S$. ruber: S. boesemani, S. camposseabrai, S.garbei, S. pachycrus, $S$. trilineatus and S. x-signatus, collected in northern and northeastern Brazil. 


\section{Materials and Methods}

Twenty one individuals of six species of Scinax from the clade $S$. ruber collected in distinct localities in northern (Bragança, PA) and northeastern (Maracás and Jequié, BA) Brazil were cytogenetically analyzed (Table 1). The specimens were deposited in the Herpetological Collection at Universidade Estadual de Santa Cruz (UESC). Metaphasic chromosomes were obtained from cells of intestinal epithelium as described by Schmid (1978). Slides were stained with $10 \%$ Giemsa solution in phosphate buffer $0.1 \mathrm{M}(\mathrm{pH}$ 6.8) for about $10 \mathrm{~min}$, washed in distilled water and air dried. The best metaphases were selected and photographed for karyotyping and chromosomal measurements. Active nucleolar organizer regions (Ag-NORs) were located by silver nitrate staining (Howell and Black, 1980), and heterochromatin was detected by C-banding according to Sumner (1972), modified by Siqueira et al. (2008). Fluorochrome staining using chromomycin $\mathrm{A}_{3}\left(\mathrm{CMA}_{3}\right)$ and 4',6-diamidino-2-phenylindole (DAPI) was performed to detect GC- and AT-rich regions, respectively (Schmid, 1980). All images were captured by epifluorescence microscopy (Olympus BX-51 equipped with digital image software Image Pro-Plus version 6.2). The chromosomes were classified based on centromere position as: $\mathrm{m}$ (metacentric), sm (submetacentric) and st (subtelocentric), according to Green and Sessions (1991).

\section{Results}

All analyzed species presented a modal diploid number of $2 \mathrm{n}=24$ and $\mathrm{FN}=48$. The chromosomal morphology was similar in nearly all species, comprising eight metacentric pairs $(1,2,7,8,9,10,11$, and 12) and four submetacentric ones $(3,4,5$, and 6). However, pair 7 in $S$. boesemani was submetacentric and pairs 11 and 12 in $S$. $x$-signatus were submetacentric (Figure 1 and Table 2).

Silver nitrate staining showed that NORs were usually located on the long arms of pair 11 (11q), either at an interstitial position ( $S$. campossabrai, S. trilineatus and $S$. $x$-signatus) or in the terminal region (S. pachycrus). NORs were also detected at interstitial positions on $8 \mathrm{q}$ in $S$. boesemani and $S$. garbei. It is worthy of note that the
Ag-NORs were coincident with secondary constrictions observed in Giemsa-stained karyotypes of S. boesemani, $S$. campossabrai and S. $x$-signatus (Figure 1).

Heterochromatin was visualized at centromeric regions of most chromosomes in all species (Figure 2). In addition, some species-specific C-bands represented heterochromatin segments at telomeric regions of pairs 3 and 4 in S. boesemani (Figure 2A). S. campossabrai was characterized by the presence of exclusively centromeric C-bands in all chromosomes (Figure 2B). S. garbei and S. pachycrus presented terminal C-bands on arms of pairs 1 and 2 (Figure 2C) and pairs 1, 2, 3, 4, 5, 6, 7, and 9 (Figure 2D), respectively. $S$. $x$-signatus also presented heterochromatin at terminal regions of pair 4 (Figure 2E). Heterochromatic blocks interspersed with NORs were observed in S. garbei, S. pachycrus and S. x-signatus (Figure 2C,D,E).

Fluorochrome staining was successful in $S$. boesemani, S. pachycrus and $S$. x-signatus. In these species, GC-rich segments $\left(\mathrm{CMA}_{3}{ }^{+}\right.$and $\left.\mathrm{DAPI}^{-}\right)$were coincident with NORs (Figure 3 ). In addition, all centromeric regions of $S$. boesemani were positively stained, following the C-banding pattern (Figure 3A), while fluorescent signals were observed in several centromeres and terminal regions in $3 \mathrm{q}$ and 5 of $S$. pachycrus (Figure 3B) and in most centromeric regions of $S$. $x$-signatus (Figure 3C).

Interestingly, no chromosomal differences could be found among samples of $S$. x-signatus, in spite of a high degree of isolation by distance of collection sites from distinct biomes (Amazon in Bragança-PA and caatinga in Jequié, BA).

\section{Discussion}

We herein provide the first karyotypic data about $S$. boesemani, S. camposseabrai, S. garbei, S. pachycrus, $S$. trilineatus and $S$. x-signatus. The present results confirm the modal diploid values of 24 chromosomes and $\mathrm{FN}=48$ proposed for Scinax and most species in Hylinae (Duellman, 2001; Faivovich, 2002; Kasahara et al., 2003; Cardozo et al., 2011).

In general, the karyotype formulae are similar among species of the $S$. ruber clade. Nonetheless, we noted varia-

Table 1 - Analyzed species, number and sex of specimens $(\mathrm{N})$ and collection site.

\begin{tabular}{llcc}
\hline Species & Voucher identification & N & Locality \\
\hline S. boesemani & MZUESC12012(M) & 1 & Bragança - PA \\
S. camposseabrai & MZUESC11022(M), MZUESC11023(M), MZUESC11024(M), MZUESC11025 (F) & 4 & Maracás - BA \\
S. garbei & MZUESC12006(M), MZUESC12007(F), MZUESC12008(F), MZUESC12009(F) & 4 & Bragança - PA \\
S. pachycrus & MZUESC 11008(NI), MZUESC11035(F), MZUESC11036(M) MZUESC11037(M) & 4 & Jequié - BA \\
S. trilineatus & MZUESC12013 (M) & 1 & Bragança - PA \\
S. - signatus & MZUESC11001(M), MZUESC11010(F), MZUESC11018(NI) & 3 & Jequié - BA \\
& MZUESC12001 (M), MZUESC12002(F), MZUESC12003(F), MZUESC12004 (F) & 4 & Bragança - PA \\
\hline
\end{tabular}

M: male. F: female. 


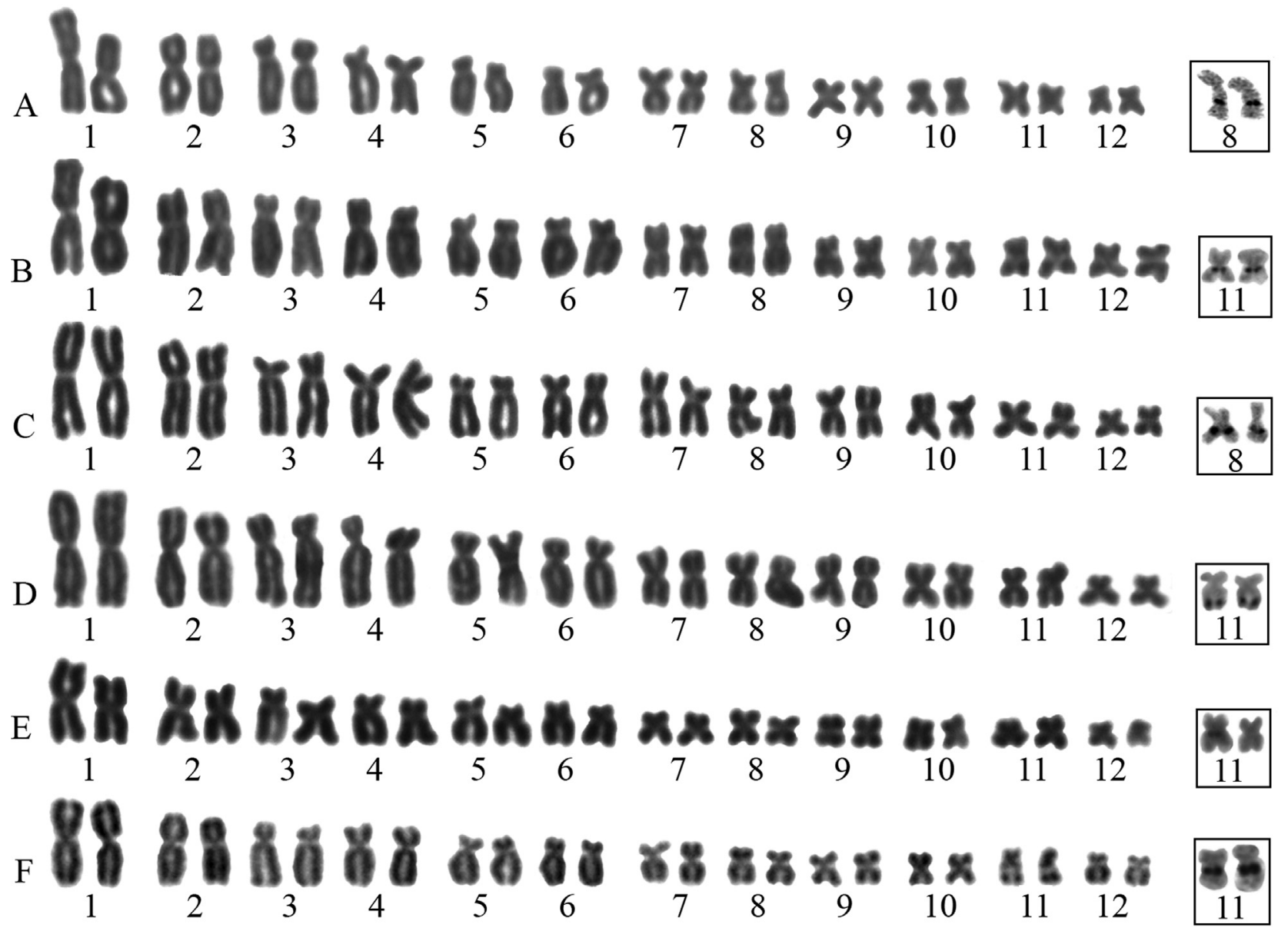

Figure 1 - Giemsa stained karyotypes of Scinax species: (A) S. boesemani, (B) S. camposseabrai, (C) S. garbei, (D) S. pachycrus, (E) S. trilineatus and (F) S. x-signatus. The NOR-bearing chromosomes after silver nitrate staining are highlighted in boxes.

tion in morphology has been reported for pairs 7, 11 and 12 from submetacentric to metacentric (Cardozo et al., 2011), as well as in pair 7 of $S$. boesemani (submetacentric) and pairs 11 and 12 (submetacentric) in $S$. x-signatus (Figure 1 and Table 1). These results suggest that microrearrangements such as deletion/duplication of chromosomal segments or inversions may have taken place independently in the abovementioned species.

The results also should prove to be useful for cytotaxonomy and systematics of Scinax species. Brusquetti et al. (2014) revised S. fuscomarginatus and related species, suggesting that $S$. trilineatus is a synonym for $S$. fuscomarginatus, since the genetic differences in $16 \mathrm{~S}$ and COI sequences could be associated with geographic distance among populations. Moreover, these authors found no signification differences in vocalization and morphometric patterns between the two putative species. On the other hand, we observed chromosomal differences between S. trilineatus ( 8 metacentric and 4 submetacentric pairs) (Table 2), and S. fuscomarginatus (6 metacentric and 6 submetacentric pairs) (Cardozo et al., 2011). Thus, the cytogenetic data support the separation of both cryptic species based on structural rearrangements, such as inversions.

The nucleolar organizer regions are also considered efficient markers for the identification of new species (Bruschi et al., 2012) or cryptic forms (Siqueira et al., 2008), as well as to establish infragenus subdivisions (Raber and Carvalho, 2004; Cardozo et al., 2011). In this sense, the Ag-NOR located at 11q is regarded as an ancestral condition in Scinax (Cardozo et al., 2011). In the present study, two species of the Amazon region ( $S$. boesemani and $S$. garbei) showed GC-rich NORs on 8q, as confirmed by Ag-NOR, C-banding and fluorochrome staining, suggesting a derived feature. An additional nucleolar region in pair 8 was also reported by Cardozo et al. (2011) in another species of $S$. ruber clade, Scinax hayii. The two species did not come out as closely related in the phylogenetic analysis carried out by Wiens et al. (2010) and, hence, the changes in Ag-NOR location should be regarded as independent events leading to convergent distribution pattern of NORs.

A single NOR-bearing chromosome was visualized in Scinax trilineatus, and this may be related to the small size of ribosomal cistrons in one homologous or an inactive 


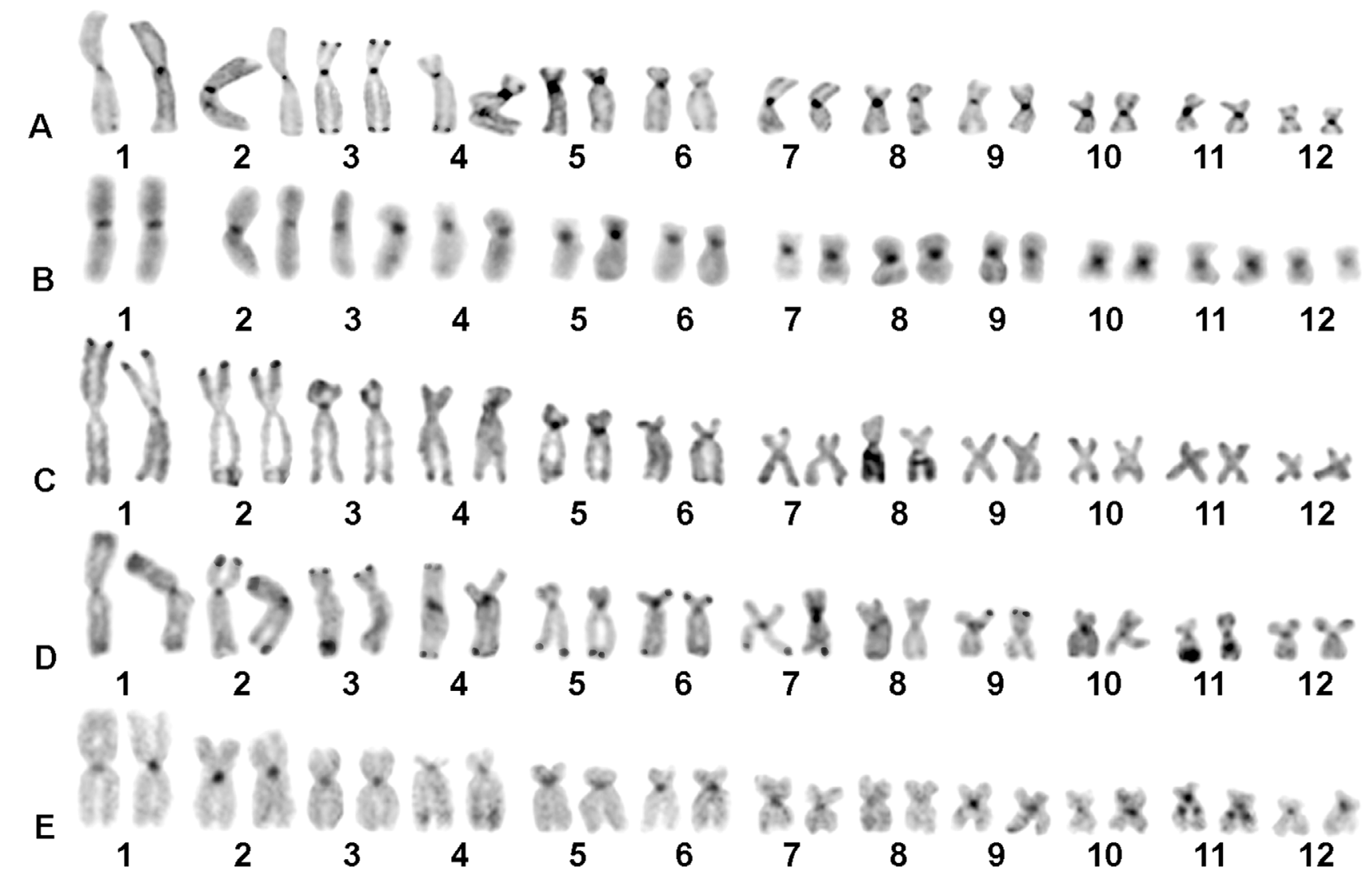

Figure 2 - C-banded karyotypes of Scinax species: (A) S. boesemani, (B) S. camposseabrai, (C) S. garbei, (D) S. pachycrus and (E) S. x-signatus.
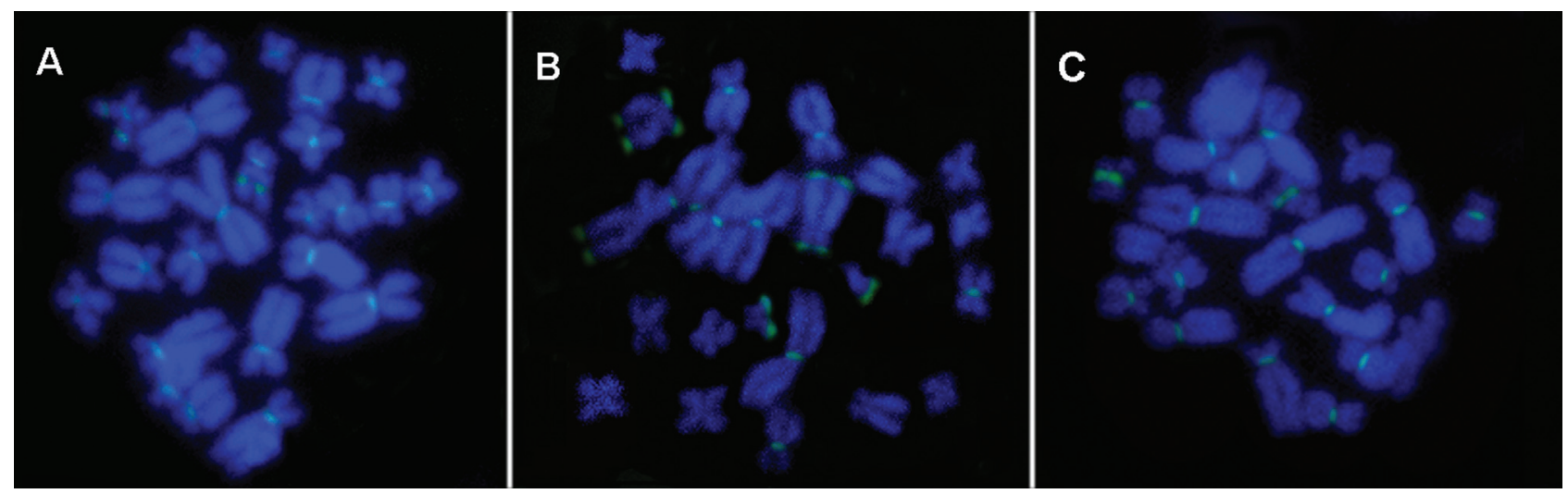

Figure 3 - Mitotic metaphases after fluorochrome staining showing $\mathrm{CMA}_{3}{ }^{+}$signals in green and chromosomes counterstained with DAPI (blue): (A) $S$. boesemani, (B) S. pachycrus and (C) S. x-signatus.

site, since silver nitrate staining can only reveal previously active NORs (Schmid, 1978; Kasahara, 2009). This AgNOR pattern is similar to that reported in Scinax alter and Scinax hiemalis (Cardozo et al., 2011).

Heterochromatin at centromeric region, as detected in this study, has been commonly reported in species of the $S$. ruber clade, such as $S$. acuminatus, $S$. alter, $S$. curicica, $S$. duartei, S. eurydice, S. fuscovarius, S. granulatus, S. hayii, S. nasicus, S. perereca, S. similis and S. squalirostris (Kasahara et al., 2003; Cardozo et al., 2011). Another com- mon feature observed in the analyzed species, except for $S$. camposseabrai, was the presence of heterochromatin interspersed with NORs, as described in $S$. argyreornatus, $S$. curicica, S. eurydice, S. hiemalis, $S$. similis and $S$. squalirostris (Cardozo et al., 2011).

A distinguishable C-banding pattern was observed in S. boesemani, S. garbei, S. pachycrus and S. x-signatus, as these species presented additional heterochromatic segments at terminal regions of some chromosomes. Even though terminal C-bands have been reported in other hylids 
Table 2 - Chromosomal measurements of analyzed species ( $R L$ - relative length; $\mathrm{CI}=$ centromeric index and $\mathrm{CT}=$ chromosomal type) according to Green and Sessions (1991).

\begin{tabular}{|c|c|c|c|c|c|c|c|c|c|c|c|c|c|}
\hline \multirow[t]{2}{*}{ Species } & & \multicolumn{12}{|c|}{ Chromosomal pairs } \\
\hline & & 1 & 2 & 3 & 4 & 5 & 6 & 7 & 8 & 9 & 10 & 11 & 12 \\
\hline \multirow[t]{3}{*}{ S. boesemani } & $\mathrm{RL}$ & 12.34 & 10.71 & 10.05 & 8.90 & 7.51 & 6.21 & 5.82 & 5.63 & 5.62 & 4.65 & 4.21 & 3.84 \\
\hline & CI & 0.49 & 0.41 & 0.29 & 0.31 & 0.25 & 0.32 & 0.30 & 0.42 & 0.47 & 0.45 & 0.47 & 0.46 \\
\hline & $\mathrm{CT}$ & M & M & SM & SM & SM & SM & SM & M & M & M & M & M \\
\hline \multirow[t]{3}{*}{ S. camposseabrai } & $\mathrm{RL}$ & 14.42 & 11.58 & 10.51 & 9.67 & 7.45 & 7.25 & 6.61 & 6.30 & 5.14 & 4.71 & 4.52 & 4.08 \\
\hline & CI & 0.46 & 0.38 & 0.28 & 0.31 & 0.25 & 0.28 & 0.41 & 0.41 & 0.44 & 0.46 & 0.45 & 0.49 \\
\hline & CT & M & M & SM & SM & SM & SM & $\mathrm{M}$ & M & M & M & M & M \\
\hline \multirow[t]{3}{*}{ S. garbei } & $\mathrm{RL}$ & 16.17 & 13.57 & 11.51 & 10.55 & 8.96 & 8.82 & 8.81 & 7.02 & 6.85 & 5.56 & 5.47 & 3.61 \\
\hline & CI & 0.46 & 0.41 & 0.29 & 0.33 & 0.25 & 0.3 & 0.38 & 0.46 & 0.39 & 0.48 & 0.46 & 0.47 \\
\hline & CT & M & M & SM & SM & SM & SM & M & M & M & M & M & M \\
\hline \multirow[t]{3}{*}{ S. pachycrus } & $\mathrm{RL}$ & 11.33 & 9.48 & 8.85 & 8.04 & 6.66 & 6.61 & 5.11 & 4.80 & 3.88 & 3.78 & 3.55 & 2.60 \\
\hline & CI & 0.46 & 0.39 & 0.25 & 0.26 & 0.26 & 0.28 & 0.42 & 0.45 & 0.45 & 0.47 & 0.4 & 0.4 \\
\hline & $\mathrm{CT}$ & M & M & SM & SM & SM & SM & M & M & M & M & M & M \\
\hline \multirow[t]{3}{*}{ S. trilineatus } & $\mathrm{RL}$ & 9.76 & 8.36 & 7.18 & 6.76 & 5.68 & 5.29 & 4.24 & 4.02 & 3.63 & 3.43 & 3.41 & 3.02 \\
\hline & CI & 0.47 & 0.43 & 0.31 & 0.3 & 0.32 & 0.28 & 0.38 & 0.45 & 0.44 & 0.47 & 0.46 & 0.49 \\
\hline & CT & M & M & SM & SM & SM & SM & M & M & M & M & M & M \\
\hline \multirow[t]{3}{*}{ S. $x$-signatus } & $\mathrm{RL}$ & 11.77 & 9.26 & 8.50 & 8.41 & 6.76 & 6.45 & 5.45 & 4.80 & 4.11 & 4.06 & 3.87 & 3.00 \\
\hline & CI & 0.48 & 0.41 & 0.27 & 0.35 & 0.27 & 0.27 & 0.41 & 0.38 & 0.47 & 0.42 & 0.28 & 0.3 \\
\hline & CT & $\mathrm{M}$ & $\mathrm{M}$ & SM & SM & SM & SM & $\mathrm{M}$ & $\mathrm{M}$ & $\mathrm{M}$ & $\mathrm{M}$ & SM & SM \\
\hline
\end{tabular}

(Busin et al., 2006; Kasahara et al., 2003; Gruber et al., 2012), this is the first description in Scinax. Therefore, C-banding patterns can be potentially used to identify species in this genus, and more studies based on this technique should be performed within Scinax.

Fluorochrome staining in amphibians usually identify GC-rich regions associated with NORs and more occasionally C-bands (Ananias et al., 2007; Campos et al., 2008). Indeed, NORs and several centromeric regions in the species anayzed herein were positively stained by $\mathrm{CMA}_{3}$. In the case of $S$. pachycrus, C-bands at telomeric regions of pairs 3 and 5 were also GC-rich, indicating a homogeneous base composition of heterochromatin. However, there are only few studies on $\mathrm{CMA}_{3}$ /DAPI staining in Scinax to provide a reliable scenario of heterochromatin composition.

In conclusion, the present work increased the number of karyotyped species in Scinax by providing the first chromosomal data in $S$. boesemani, S. camposseabrai, $S$. garbei, S. pachycrus, $S$. trilineatus and $S$. x-signatus. Comparisons with previous reports suggest that chromosomal evolution in Scinax ( $S$. ruber clade) may have been mainly driven by microstructural rearrangements and inversions associated with stable karyotype fomulae, particularly among species within a same clade (e.g. S. camposseabrai and $S$. pachycrus). As indicated by Cardozo et al. (2011), the chromosomal inversions in the clade $S$. ruber are restricted to pairs 7,11 and 12. Therefore, banding techniques should prove essential to provide cytotaxonomic markers, as observed in relation to NOR location of the Amazon species and heterochromatin distribution.

\section{Acknowledgments}

We thank Hoogmoed M. for identifying the biological material from the Amazon site. Financial support to this work was provided by Fundação de Amparo à Pesquisa do Estado da Bahia (FAPESB: PET 035/2010).

\section{References}

Ananias FAL, Bombeiro CDB, Silva APZ, Haddad CFB and Kasahara S (2007) Cytogenetics of Eupemphix nattereri Steindachner, 1863 (Anura, Leiuperidae) and karyotypic similarity with species of related genera: Taxonomic implications. Acta Zool Sin 53:285-293.

Bruschi DP, Busin CV, Siqueira S and Recco-Pimentel SM (2012) Cytogenetic analysis of two species in the Phyllomedusa hypochondrialis group (Anura, Hylidae). Hereditas 40:34-40.

Brusquetti F, Jansen M, Barrio-Amorós C, Segalla M and Haddad, CFB (2014) Taxonomic review of Scinax fuscomarginatus (Lutz, 1925) and related species (Anura, Hylidae). Zool J Linnean Soc Society 171:783-821.

Busin CS, Lima AP, Prado CPA, Strüssmann C, Siqueira S and Recco-Pimentel MS (2006) Chromosomal differentiation of populations of Lysapsus limellus limellus, L. l. bolivianus, and of Lysapsus caraya (Hylinae, Hylidae). Micron 37:355-362.

Campos JRC, Ananias F, Haddad CFB and Kasahara S (2008) Karyotypic similarity among Barycholos ternetzi and five 
species of the genus Eleutherodactylus from southeastern Brazil (Anura, Brachycephalidae). Micron 39:151-159.

Cardozo DE, Leme DM, Bortoleto JF, Catroli GF, Baldo DF, Faivovich J, Kolenc F, Silva APZ, Borteiro C, Haddad CFB et al. (2011) Karyotypic data on 28 species of Scinax (Amphibia, Anura, Hylidae): Diversity and informative variation. Copeia 2:251-263.

Duellman WE (2001) The Hylid Frogs of Middle America. Society for the Study of Amphibians and Reptiles, Ithaca, $1180 \mathrm{pp}$.

Faivovich J (2002) A cladistic analysis of Scinax (Anura, Hylidae). Cladistics 18:367-393.

Faivovich J, Haddad CFB, Garcia PC, Frost DR, Campbell J and Wheeler WC (2005) Systematic review of the frog family Hylidae, with special reference to Hylinae: Phylogenetic analysis and taxonomic revision. Bull Am Mus Nat Hist 294:6-75.

Green DM and Sessions SK (1991) Nomenclature for chromosomes. In: Green DM and Sessions SK (eds) Amphibian Cytogenetics and Evolution. Academic Press, San Diego, pp. 431-432.

Gruber SL, Zina J, Narimatsu H, Haddad CFB and Kasahara S (2012) Comparative karyotype analysis and chromosome evolution in the genus Aplastodiscus. BMC Genet 13:e28.

Howell WM and Black DA (1980) Controlled silver-staining of nucleolus organizer regions with a protective colloidal developer. Experientia 8:1014-1015.

Kasahara S (2009) Introdução à Pesquisa em Citogenética de Vertebrados. Sociedade Brasileira de Genética, Ribeirão Preto, 160 pp.

Kasahara S, Silva AP, Gruber SL and Haddad CFB (2003) Comparative cytogenetic analysis on four tree frog species (Anura, Hylidae, Hylinae) from Brazil. Cytogenet Genome Res 103:155-162.
Nunes RRA and Fagundes V (2008) Cariótipos de oito espécies de anfíbios das subfamílias Hylinae e Phyllomedusinae (Anura, Hylidae) do Espírito Santo, Brasil. Bol Mus Biol Mello Leitão 23:21-36.

Pombal JJP, Haddad CFB and Kasahara S (1995) A new species of Scinax (Anura, Hylidae) from southeastern Brazil, with comments on the genus. J Herpetol 29:1-6.

Raber SC and Carvalho KA (2004) Chromosomal characterization of Hyla bischoffi and Hyla guentheri (Anura, Hylidae). Phyllomedusa 3:43-49.

Schmid M (1978) Chromosome banding in Amphibia I. Constitutive heterochromatin and nucleolus organizer regions in Bufo and Hyla. Chromosoma 66:361-388.

Schmid M (1980) Chromosome banding in Amphibia. IV. Differentiation of GC- and AT-rich chromosome regions in Anura. Chromosoma 77:83-103.

Siqueira S, Aguiar O, Strussmann C, Del-Grande ML and ReccoPimentel MS (2008) Chromosomal analysis of three Brazilian "Eleutherodactyline" frogs (Anura, Terrarana), with suggestion of a new species. Zootaxa 1860:51-59.

Sumner AT (1972) A simple technique for demonstrating centromeric heterochromatin. Exp Cell Res 75:304-306.

Wiens JJC, Kuczynski CA, Hua X and Moen DS (2010) An expanded phylogeny of treefrogs (Hylidae) based on nuclear and mitochondrial sequence data. Mol. Phylogenet Evol 55:871-882.

\section{Internet Resources}

Frost DR (2014) Amphibian Species of the World: An Online Reference. Version 6.0. American Museum of Natural History, New York, USA. http://research.amnh.org/herpetology/amphibia/index.html. Accessed July 24, 2014.

Associate Editor: Yatiyo Yonenaga-Yassuda

License information: This is an open-access article distributed under the terms of the Creative Commons Attribution License, which permits unrestricted use, distribution, and reproduction in any medium, provided the original work is properly cited. 